\title{
Developing communities: the Ford Foundation and the global urban crisis, 1958-66†
}

\author{
Sam Collings-Wells \\ Faculty of History, University of Cambridge, West Road, Cambridge, CB3 9EF, UK \\ Corresponding author. E-mail: sc940@cam.ac.uk
}

\begin{abstract}
Between 1958 and 1966 the Ford Foundation embarked on a series of pilot projects of 'urban community development' in India and the United States. This article will highlight how both of these programmes emerged in response to what Ford officials understood to be a global urban crisis, caused by the migration of 'backward' rural populations into the cities. Rather than modernizing under the pressure of urban living, these newcomers appeared to be pooling into pockets of underdevelopment - 'ghettos' in the United States and 'slums' in India. Ford sought to tackle the problem by encouraging the participation of these marginalized communities in the process of urban renewal, a strategy intended to engineer the psychological modernization of their residents. In practice, however, Ford struggled to control the channels into which these mobilizations flowed, with poor urban residents utilizing the projects to push for radical changes concerning housing, policing, and tenant-landlord relations.
\end{abstract}

Keywords: anti-poverty; community; great society; migration; philanthropy

On 10 October 1956, luminaries from the world of urban planning were invited for a two-day conference at the Ford Foundation. Now one of the world's largest philanthropic organizations, Ford was seeking to rejuvenate its programming towards the cities of the United States, which were increasingly plagued by the constellation of issues surrounding racism, suburbanization, and physical blight which historians would later term 'the urban crisis'. ${ }^{1}$ Yet as the conferees gathered at the Ford's New York offices, they were presented with an agenda encouraging them to conceptualize this crisis in a very specific way: 'Explore the major problems of urban development in the United States and the less economically developed countries,' it read, 'and whether there is a set of common principles on which these problems can be attacked.'

\footnotetext{
${ }^{\dagger}$ My thanks go to Andrew Preston and Jade Pallister for their close reading of early drafts, as well as the two anonymous peer reviewers, all of whom made suggestions which improved the quality of the article. I would like to thank the archivists at the Rockefeller Archive Center. I am also extremely grateful to Matthew Hull and Aarti Sethi, for kindly providing me with their copies of the documents from the Delhi archives, without which this article would not have been possible. Any errors are my own.

${ }^{1}$ Thomas Sugrue, The Origins of the Urban Crisis: Race and Inequality in Postwar Detroit (Princeton: Princeton University Press, 1996).

${ }^{2}$ Abridged transcript of Conference on Urban Planning \& Development held at the Ford Foundation, 10-11 October 1956, report no. 003477, 1, box 154, reports 3255-6261 (FA739B), catalogued reports, Ford Foundation Archives, Rockefeller Archive Center, Sleepy Hollow, NY (hereafter cited as FF, RAC).

(C) The Author(s), 2020. Published by Cambridge University Press. This is an Open Access article, distributed under the terms of the Creative Commons Attribution-NonCommercial-NoDerivatives licence (http://creativecommons.org/licenses/by-nc-nd/4.0/), which permits non-commercial re-use, distribution, and reproduction in any medium, provided the original work is unaltered and is properly cited. The written permission of Cambridge University Press must be obtained for commercial re-use or in order to create a derivative work.
} 
The conferees took up the challenge enthusiastically. There was a growing 'world-wide preoccupation with urbanization', argued Anatole Solow of the Pan American Union. This was coupled with a recognition that, when it came to urban affairs at least, both 'less developed and more developed countries are facing the same general problems'. The housing expert Phillip Hauser agreed, pointing to the potential of 'training personnel simultaneously in a less developed area and in a developed country'. Summarizing proceedings for Paul Ylvisaker - the newly appointed director of Public Affairs who would set the direction of Ford's urban programming over the next few years - attendees urged the Foundation to focus on 'the inter-relation of urbanism as it grows in the United States and as it grows in less developed countries'. ${ }^{3}$

Through the rest of the decade and into the 1960s the Ford Foundation duly responded to this call. Placing the post-war decline of America's cities in an international context, its officials conceptualized the urban crisis as being part of a global developmental problem caused by the rapid and unplanned migration of 'backward' populations from rural to urban areas. This was an urban crisis which transcended the boundaries of Global North and South, 'developed' and 'underdeveloped', stretching from Oakland and Detroit to Mexico City, Delhi, Jakarta, and Lagos. Just as the rapid pace of urbanization throughout the Global South was thought to be generating an array of social and physical problems - poor sanitation, inadequate housing, juvenile delinquency - the internal migration of 'southern blacks' and Puerto Rican people was stigmatized as exporting 'underdevelopment' into the cities of the United States. ${ }^{4}$

What is more, thinking about the urban crisis through the prism of international development encouraged the Ford Foundation to cycle techniques freely between their programming at home and abroad. This article will explore one dimension of this process by focusing on Ford's pilots projects in Delhi and five US cities at the turn of the 1960s. In both, the Foundation turned to a strategy of 'urban community development', seeking to engineer the psychological development of 'backward' rural newcomers by enlisting their participation in the process of city renewal. Pioneered during Ford's pilot project in Delhi begun in 1958 - and continued into its 'Gray Areas' programme in the United States shortly afterwards - this was a strategy which would ultimately form the basis for the 'Maximum Feasible Participation' clause of Lyndon Johnson's Economic Opportunity Act (1964).

By holding Ford's domestic and overseas programming in a single analytical frame, this article will offer a fresh perspective on the scholarship on the origins of community action within the United States. ${ }^{5}$ Scholars in this field have frequently noted the connections between the Ford Foundation's Gray Areas programme and Johnson's War on Poverty. ${ }^{6}$ More recently, historians such as Daniel Immerwahr and Nicole Sackley have transnationalized this account, arguing that community development strategies were initially tested in the villages of India through the Fordsponsored pilot project in Etawah, Uttar Pradesh. Focusing primarily on these rural development projects, a standard narrative has emerged whereby the community methods honed in the villages

\footnotetext{
${ }^{3}$ Ibid., 12, 5, 10 .

${ }^{4}$ Dyke Brown, 'Culturally Disadvantaged Youth in the American City', 13 November 1962, report no. 018659, 1, reports 17727-19980 (FA739G), catalogued reports, FF, RAC.

${ }^{5}$ Ananya Roy, Emma Shaw Crane, and Stuart Schrader, 'Gray Areas: The War on Poverty at Home and Abroad', in Territories of Poverty: Rethinking North and South, ed. Ananya Roy and Emma Shaw Crane (Athens, GA: University of Georgia Press, 2015), 289-314.

${ }^{6}$ See, for example, Alice O'Connor, 'Community Action, Urban Reform, and the Fight Against Poverty: The Ford Foundation's Gray Areas Program', Journal of Urban History 22, no. 5 (1996): 586-625; Alice O'Connor, Poverty Knowledge: Social Science, Social Policy, and the Poor in Twentieth Century U.S. History (Princeton: Princeton University Press, 2001), chap. 5; Noel Cazenave, Impossible Democracy: The Unlikely Success of the War on Poverty Community Action Program (Albany: State University of New York Press, 2008); and Roger Biles, The Fate of Cities: Urban America and the Federal Government, 1945-2000 (Lawrence, KS: University Press of Kansas, 2011), 115.
} 
of the Global South circulated back to the cities of the United States: 'the boomerang returning home', as Immerwahr put it. ${ }^{7}$

By arguing that community strategies returned to urban America from rural India, this approach underplays how simultaneous projects of urban community development unfolded in the United States and overseas. Indeed, while the Ford Foundation's Uttar Pradesh project has become something of a cause célèbre for historians of development, with a few notable exceptions strikingly little attention has been paid to the organization's urban activities abroad. ${ }^{8}$ This is emblematic of a trend in the broader US foreign relations literature, whereby the metropolitan dimensions of modernization and development have been overlooked in favour of the agricultural, demographic, and military aspects. ${ }^{9}$ In Michael Latham's most recent synthesis of the literature, for instance, individual chapters are devoted to demographers, agronomists, and military-led modernization regimes. Notably absent is any discussion of urban planners. ${ }^{10}$

This neglect has skewed our understanding of US development efforts. A common assumption running through much of this scholarship is that experts imagined the United States to be confidently perched at the peak of the developmental ladder, a position which justified the onedirectional export of US expertise to the rest of the 'underdeveloped' world. This is largely because historians have focused on those areas of developmental expertise - in agriculture, population control, and industrial strategy - which worked to buttress exceptionalizing tendencies within the United States. Yet, when it came to urban affairs, the decaying state of America's own cities mitigated against such a self-confident and unidirectional assertion of influence. By focusing on the intersection between urbanism and international development, this article will bring to the fore a modernization problem which appeared to cut across the United States itself.

Its solution was accordingly energized by transnational networks of expertise and intellectual exchange. In India, the idea of tackling urban deprivation at the level of the community emerged from debate over the relationship between urbanization, development, and delinquency - one which was playing out in other rapidly urbanizing nations across the Global South. With rural residents drifting into the cities, informal social bonds which previously regulated 'deviant' behaviour were understood to be eroding and spawning an epidemic of urban crime. Ford utilized these

${ }^{7}$ Daniel Immerwahr, Thinking Small: The United States and the Lure of Community Development (Cambridge, MA: Harvard University Press, 2015). See also Nicole Sackley, 'The Village as Cold War Site: Experts, Development, and the History of Rural Reconstruction', Journal of Global History 6, no. 3 (2011): 481-504; Nicole Sackley, 'Village Models: Etawah, India, and the Making and Remaking of Development in the Early Cold War', Diplomatic History 37, no. 4 (2013): 749-78; Nick Cullather, Hungry World: America's Cold War Battle against Poverty in Asia (Cambridge, MA: Harvard University Press, 2010); Sheyda Jahanbani, 'One Global War on Poverty: The Johnson Administration Fights Poverty at Home and Abroad, 1964-1968', in Beyond the Cold War: Lyndon Johnson and the New Global Challenges of the 1960s, ed. Francis J. Gavin and Mark Atwood Lawrence (New York: Oxford University Press, 2014), 97-113. For a recent work which explores the influence of Latin American developmentalism on the US welfare state, see Amy Offner, Sorting Out the Mixed Economy: The Rise and Fall of Welfare and Developmental States in the Americas (Princeton: Princeton University Press, 2019).

${ }^{8}$ The exception is Matthew Hull's superb 'Communities of Place, Not Kind: American Technologies of Neighborhood in Postcolonial Delhi', Comparative Studies in Society and History 53, no. 4 (2011): 757-90.

${ }^{9}$ A historiographical point effectively made by Simon Toner, 'The Counter-Revolutionary Path: South Vietnam, the United States, and the Global Allure of Development, 1968-1973' (PhD diss., London School of Economics, 2015).

${ }^{10}$ Michael Latham, The Right Kind of Revolution: Modernization, Development, and U.S. Foreign Policy from the Cold War to the Present (Ithaca: Cornell University Press, 2010). For rural development, see Cullather, Hungry World; Tore Olsson, Agrarian Crossings: Reformers and the Remaking of the US and Mexican Countryside (Princeton: Princeton University Press, 2017); Prakash Kumar et al., 'Roundtable: New Narratives of the Green Revolution', Agricultural History 91, no. 3 (2017): 397-422; Jack Loveridge, 'Between Hunger and Growth: Pursuing Rural Development in Partitions Aftermath', Contemporary South Asia 25, no. 1 (2017): 56-69; Courtney Fullilove, The Profit of the Earth: The Global Seeds of American Agriculture (Chicago: University of Chicago Press, 2017); Benjamin Robert Siegel, 'Whither Agriculture? The "Green Revolution" at 50', Public Books (January 2019), https://www.publicbooks.org/whither-agriculture-the-greenrevolution-50/. 
observations to shine a light on the situation in the United States, which also appeared to be experiencing its own increasingly racialized 'crisis' of urban crime and juvenile delinquency.

Foregrounding these transnational exchanges can help deepen our understanding of the evolving intersections of delinquency, crime control, and community development in US cities during the 1960s. Recently, many of these issues have been addressed by historians working in the burgeoning field exploring the origins of mass incarceration. ${ }^{11}$ The pioneering work of Elizabeth Hinton and Julilly Kohler-Haussmann, for instance, has shown how community development efforts quickly became subsumed into the 'War on Crime' in the wake of urban uprisings in cities across the United States. ${ }^{12}$ A close focus on Ford's overseas programming adds a global dimension to this US-centred narrative. ${ }^{13}$ By examining urban community development projects abroad, we can more clearly see the extent to which crime prevention was baked into their developmental mission from the start; delinquency and crime were to be prevented through the participation and concomitant 'modernization' of deprived urban communities.

Yet despite this emphasis on crime control, in practice urban community development proved far more combustible than its rural counterpart. After encouraging the participation of impoverished residents in the process of urban renewal, the Ford Foundation struggled to control the channels into which this discontent flowed. In both India and the United States, attempts to organize communities around relatively 'non-political' problems - garbage disposal, remedial education, women's sewing classes - frequently ran up against the more radical demands of the residents, who wanted to organize instead around the fraught issues of policing, unresponsive municipal authorities, and tenant-landlord relations. While participation in the process of city regeneration was theoretically supposed to generate a consensual process of social change 'modernizing' rural in-migrants - in practice it led to high-profile conflicts with established local power structures.

\section{A global urban crisis}

By the late 1940s the Ford Foundation was beginning to transform itself from a family tax haven into one of the most well-endowed philanthropic organizations in the world. ${ }^{14}$ One of the key documents of this transition was the blandly titled Report of the Study for the Ford Foundation on Policy and Program (1949). Known simply as the 'Gaither Report' after its principal author, Rowan Gaither, its task was to survey both the domestic and the international scene for potential trouble spots ripe for Ford Foundation intervention. ${ }^{15}$ Infused throughout the report was what Karen Ferguson has described as a 'developmentalist creed', an embryonic iteration of modernization theory which rested on the belief that the principal root of unrest throughout the world

\footnotetext{
${ }^{11}$ The field has expanded enormously in the past decade. For key introductory works, see Heather Ann Thompson, 'Why Mass Incarceration Matters: Rethinking Crisis, Decline, and Transformation in Postwar American History', Journal of American History 97, no. 3 (2010): 703-34; Michelle Alexander, The New Jim Crow: Mass Incarceration in the Age of Colorblindness (New York: The New Press, 2010); Kelly Lytle Hernández, Khalil Gibran Muhammad, and Heather Ann Thompson, 'Introduction: Constructing the Carceral State', Journal of American History 102, no. 1 (2015): 18-24; and Donna Murch and Heather Ann Thompson, 'Rethinking Urban America through the Lens of the Carceral State', Journal of Urban History 41, no. 5 (2015): 251-5.

${ }^{12}$ Elizabeth Hinton, From the War on Poverty to the War on Crime: The Making of Mass Incarceration in America (Cambridge, MA: Harvard University Press, 2016); Julilly Kohler-Haussmann, Getting Tough: Welfare and Imprisonment in 1970s America (Princeton: Princeton University Press, 2017).

${ }^{13}$ For a superb pioneering example of a work which seeks to 'globalize' the US carceral state literature, see Stuart Schrader, Badges Without Borders: How Global Counterinsurgency Transformed American Policing (Berkeley: University of California Press, 2019).

${ }^{14}$ Karen Ferguson, Top-Down: The Ford Foundation, Black Power, and the Reinvention of Racial Liberalism (Philadelphia: University of Pennsylvania Press, 2013), chap. 1.

${ }^{15}$ H. Rowan Gaither, ed., Report of the Study for the Ford Foundation on Policy and Program (Detroit: Ford Foundation, 1949).
} 
was the difficulty of managing the transition from 'backwardness' to 'modernity'. ${ }^{16}$ A problem of psychological and behavioural adjustment, the report noted how it could manifest itself anywhere - even in ostensibly 'developed' nations such as the United States. The difference was that throughout the Global South the site of these transitional strains were presented as occurring primarily in the rural areas, while in the United States they were understood to be coalescing around its decaying urban cores. ${ }^{17}$

Initially, therefore, Foundation programming during the early 1950s bifurcated between the predominantly rural projects undertaken abroad and the urban interventions at home. These domestic efforts - some of which strayed dangerously close to the highly charged issues of racism and segregation - quickly became embroiled in a series of McCarthyite congressional investigations in the early 1950s. With opportunities at home circumscribed by these controversies, Ford opted to dramatically expand its programming overseas. As numerous historians have shown, this involved initiating pilot projects in rural community development, funding the establishment of universities, and participating in the industrial planning efforts of postcolonial governments. ${ }^{18}$ Far less commented upon, however, was the fact that the Foundation also began to engage with the field of 'international urbanism', acquainting itself with the problems and programmes of metropolitan development taking place around the world. ${ }^{19}$

As Ford Foundation field offices sprung up around the globe, its central headquarters in New York was transformed into a clearing house for developmental knowledge. This was an institutional structure which encouraged transnational comparisons, as well as the collapsing of foreign and domestic problems into a single analytical frame. And, in sharp contrast to its work in rural development, the urban problems encountered throughout the Global South appeared to share distinct similarities with those plaguing the metro regions of the United States. In particular, officials began detecting parallels between the process of urbanization occurring throughout the 'underdeveloped world' and the migration of African American and Puerto Rican people to the cities of the United States. ${ }^{20}$ Both were understood to be part of a global process of 'marginal' communities drifting into the cities, a trend which was generating analogous problems of crime, underemployment, inadequate housing, and poor sanitation. ${ }^{21}$

This focus on rural-urban migration ensured that the global urban crisis was conceptualized as a developmental problem which required the psychological modernization of these recent arrivals. Foundation reports from the field throughout the Global South regularly characterized urban newcomers as 'backward' and 'marginal', with their 'culturally deprived backgrounds' ensuring

\footnotetext{
${ }^{16}$ Ferguson, Top-Down, 32-3.

${ }^{17}$ Gaither, Report of the Study, 45.

${ }^{18}$ These have been covered extensively by historians. See Edward H. Berman, Influence of the Carnegie, Ford, and Rockefeller Foundations on American Foreign Policy: The Ideology of Philanthropy (Albany: State University of New York Press, 1984); Kathleen D. McCarthy, 'From Government to Grass-Roots Reform: The Ford Foundation's Population Programmes in South Asia, 1959-1981', Voluntas: International Journal of Voluntary and Nonprofit Organizations 6, no. 3 (1995): 292-316; Matthew Connelly, Fatal Misconception: The Struggle to Control World Population (Cambridge, MA: Harvard University Press, 2008); Inderjeet Parmer, Foundations of the American Century: The Ford, Carnegie, and Rockefeller Foundations in the Rise of American Power (New York: Columbia University Press, 2012); Nicole Sackley, 'Foundation in the Field: The Ford Foundation New Delhi Office and the Construction of Development Knowledge, 1951-1970', in American Foundations and the Coproduction of World Order in the Twentieth Century, ed. Ulriche Herbert and Leonhard John (Göttingen: Vandenhoeck \& Ruprecht, 2012), 232-60; Immerwahr, Thinking Small.

${ }^{19}$ Louis Winnick, 'Philanthropies Adaption to the Urban Crisis', 1989, report no. 012158, no. 11, box 575, reports 11775-13948 (FA739E), catalogued reports, FF, RAC.

${ }^{20}$ See Bernard Loshbough, 'Calcutta Metropolitan Planning Organization: Report and Recommendations', 1 May 1962, report no. 000687, 18, box 35, reports 1-3254 (FA739A), catalogued reports, FF, RAC. See also Francis X. Sutton, 'The Ford Foundation's Urban Programs Overseas: Change and Continuities', 2000, 9, folder 602, box 67, Francis X. (Frank) Sutton Papers (FA1141), FF, RAC.

${ }^{21}$ This was a view which was crystallized most clearly in the Ford Foundation consultant Marshall Clinard's Slums and Community Development: Experiments in Self-Help (New York: The Free Press, 1966).
} 
they remained isolated from 'mainstream society'.22 Writing from Delhi, Marshall Clinard bemoaned the 'feeling of apathy and futility [that] is all too common' among migrants from rural areas, which, he argued, greatly exacerbated the 'degraded' state of India's cities. ${ }^{23}$ As he later wrote, 'The Indian slum is far more complex than the mere aggregate of these appalling surroundings suggests. It is a way of life', and one which was being imported from the countryside into the city. $^{24}$

It was understood to be a way of life in America's 'ghettos', too, a view succinctly outlined in 1962 by the Foundation vice-president Dyke Brown during a high-profile speech in St Louis. For more than a hundred years, Brown told his audience, the rural poor had drifted into America's cities from Europe's overpopulated countryside, finding a felicitous combination of unskilled jobs and social mobility. Since the Second World War, however, rural migrants were increasingly coming from within the borders of the United States. Moreover, Brown argued that, in contrast to the 'hardy' European pioneers who preceded them, these new migrants were the 'culturally disadvantaged ... Negroes and Puerto Ricans, Spanish Americans and Indians, marginal farmers and hillbillies', who struggled to bridge the chasm between rural and urban life. ${ }^{25}$

Remarkably, then, a combination of the Great Northward Migration and America's overseas colonial entanglements seemed to have created a developmental problem within the United States itself, one which closely mirrored the situation in the Global South. ${ }^{26}$ As one official Ford Foundation history of this period makes clear, for many of its officials there 'were quite obvious similarities between the migration of rural Southern blacks to become mostly poor populations in American cities, and the remarkable growth of Third World cities'. ${ }^{27}$

The discovery of pockets of 'backwardness' in cities around the world served to destabilize one of the most influential theories of development - modernization theory. This was because, in this schema, development was supposed to be synonymous with urbanization. '[T]he core process of modernization' was how urban growth was described in Emerging Nations (1961), a collaborative MIT study whose star-studded list of contributors - Walt Rostow, Ithiel de Sola Pool, Lucian Pye, and Paul Rosenstein-Rodan - reads like a Who's Who of modernization theory. ${ }^{28}$ For these figures, urbanization was not only symptomatic of development but fundamental to its continuance; cities were the crucibles of modernity, acting as 'advanced enclaves in societies still predominately rural and primitive'. ${ }^{29}$ Yet, if urbanization was supposed to lead inexorably to modernization, then the location of underdeveloped communities within the city presented something of a problem.

\footnotetext{
${ }^{22}$ John Friedman, 'The Ford Foundation Urban \& Regional Development Advisory Program in Chile', June 1966, report no. 001964, 3-4, box 75, reports 1-3254 (FA739A), catalogued reports, FF, RAC; David Hunter, 'Review of Opportunities for a Ford Foundation Grant for Community Development and Municipal Improvement in Venezuela', October 1962, 9, box 16, reports 1-3254 (FA739), catalogued reports, FF, RAC; Sri Bimalananda Chatterjee, Ford Foundation Program Letter from India: Report no. 132, 'The Delhi Urban Community Development Project, India', 12 July 1962, report no. 001824, 11-12, box 70, reports 1-3254 (FA739A), catalogued reports, FF, RAC; Sidney Wilfred Mintz, 'Latin America: A Preliminary Report of Development and Development Possibilities', 1958, report no. 000002, 99-100, box 1, reports 1-3254 (FA739A), catalogued reports, FF, RAC.

${ }^{23}$ Marshall Clinard, 'Urban Community Development in India', 1959, report no. 003322, 1-2, box 147, reports 3255-6261 (FA739B), catalogued reports, FF, RAC.

${ }^{24}$ Clinard, Slums and Community Development, 73.

${ }^{25}$ Brown, 'Culturally Disadvantaged Youth', 1.

${ }^{26}$ For the Great Northward Migration, see James N. Gregory, The Southern Diaspora: How the Great Migrations of Black and White Southerners Transformed America (Chapel Hill: University of North Carolina Press, 2005). For America's overseas possessions, see Daniel Immerwahr, How to Hide an Empire: A History of the Greater United States (New York: Farrar, Straus and Giroux, 2019).

${ }^{27}$ Sutton, 'Ford Foundation's Urban Programs Overseas', 9.

${ }^{28}$ Max Millikan and Donald L. M. Blackmer, eds., Emerging Nations: Their Growth and United States Policy (Boston: Little, Brown \& Company, 1961), 27.

${ }^{29}$ Committee on Foreign Relations, Economic, Social, and Political Change in the Underdeveloped Countries and Its Implications for United States Policy: A Study Prepared for the Senate Committee on Foreign Relations by the MIT Center for International Studies (Washington, DC: Government Printing Office, 1960).
} 
The global urban crisis tugged at the edges of modernization theory by severing the causal link between urbanity and modernity. The Ford Foundation itself was well aware of this; as one of its global surveys pointed out, "the "urban crisis" is all the more distressing in light of the generally held view that urban centers are important arenas for the process of social development and change within less developed regions of the world'. ${ }^{30}$

The Foundation also challenged the exceptionalizing narratives which lay at the heart of modernization theory, undercutting previously rigid dichotomies between the 'developed' and 'underdeveloped' world. ${ }^{31}$ This was vividly demonstrated by the proceedings of the 1956 conference held at the Ford Foundation's New York offices. In contrast to the likes of Rostow and Lerner, the urbanists who attended this conference did not assume that the United States was perched at the pinnacle of the developmental ladder. ${ }^{32}$ Rather, they acknowledged that the dire state of US cities ensured that they had as much to learn from 'underdeveloped' countries as they had to teach. It is this which meant that Robert Mitchell encouraged the Foundation to utilize the lessons of it had gleaned from its urban programming for use back home: 'It could throw into sharp relief the situation of the city in the United States', he argued. ${ }^{33}$ Marshall Clinard agreed, noting at a separate symposium in Ahmedabad that 'the philosophy and techniques of urban community development programmes may become one of the most exportable contributions of underdeveloped countries to their ostensibly more highly developed brethren' ${ }^{34}$

\section{Developing communities}

As this speech from Clinard indicated, it was at the level of the 'community' that the most innovative strategies for combatting the global urban crisis had emerged - and did so largely outside the borders of the United States. Strands of this approach were certainly present within the US: as Alice O'Connor has shown, there has been a long tradition of ameliorating the strains of city living by focusing on the block or neighbourhood level. ${ }^{35}$ Yet the impulse to leverage the urban community as a solution to problems of 'underdevelopment' drew force from the rapidly urbanizing economies of the Global South. This was particularly the case in India, where these trends were generating a lively internal debate surrounding the cluster of issues of rural-urban migration, development, and crime and delinquency.

These debates among India's elites centred on the place of the city in the nation's modernization strategy. Discussions of the metropolitan dimensions of development infused the early publications of India's Planning Commission. Its First Five Year Plan (1953) expressed concern that growth was leading to the 'overcrowding of industrial centers', with 'large sections of their populations' forced to 'live in slums, huddled together in jerry-built houses or mud-huts, without water and electricity'. ${ }^{36}$ By 1956 the problem had become particularly acute, with the Commission warning that, 'unless there is adequate forethought and planning, industrial progress

\footnotetext{
${ }^{30}$ Ford Foundation International Urbanization Survey, 'Urbanization in the Developing Countries: The Response of International Assistance', 1972, report no. 011294, 3, box 458, reports 9287-11774 (FA739D), catalogued reports, FF, RAC.

${ }^{31}$ Nils Gilman, Mandarins of the Future: Modernization Theory in Cold War America (Baltimore: John Hopkins University Press, 2003); David Milne, America's Rasputin: Walt Rostow and the Vietnam War (New York: Hill \& Wang, 2008); Michael Latham, The Right Kind of Revolution: Modernization, Development, and U.S. Foreign Policy from the Cold War to the Present (Ithaca: Cornell University Press, 2010); David Ekbladh, The Great American Mission: Modernization and the Construction of an American World Order (Princeton: Princeton University Press, 2010).

${ }^{32}$ Walt Rostow, The Stages of Economic Growth: A Non-Communist Manifesto (Cambridge: Cambridge University Press, 1960); Daniel Lerner, The Passing of Traditional Society: Modernizing the Middle East (Glencoe, IL: Free Press, 1958).

${ }^{33}$ Transcript of Conference on Urban Planning \& Development, 10.

${ }^{34}$ Marshall Clinard, 'Urban Community Development and Urban Problems: A Paper Presented at the Symposium on Urban Community Development, Ahmedabad', April 1963, report no. 004759, 13, box 212, reports 3255-6261 (FA739B), catalogued reports, FF, RAC.

${ }^{35}$ O'Connor, Poverty Knowledge.

${ }^{36}$ Government of India Planning Commission, First Five Year Plan (New Delhi: GoI Publications Division, 1953 ), 233.
} 
will be accompanied by serious social and other problems in urban areas which could become increasingly difficult to manage'. ${ }^{37}$ Early efforts by the Government of India to tackle the problem focused on top-down strategies of clearance and physical regeneration. The centrepiece of this was the Slum Areas Act of 1956, which empowered municipal authorities to demolish settlements 'unfit for human habitation' and sell the land to private developers. ${ }^{38}$

Yet many argued that this approach was failing to tackle the underlying 'cultural' dimension of India's urban crisis. Sociological studies of India's 'slums' not only catalogued their physical problems but also pathologized their inhabitants, delineating a host of behavioural deficiencies that underpinned the disordered metropolitan environment. K. N. Venkatarayappa's survey of Mysore depicted its inhabitants as 'socially maladjusted', plagued by 'family disorganisation' and 'the rise of prostitution, delinquency, gambling and gangsterism'. ${ }^{39}$ Scholars attributed these trends to the deleterious impact of urbanization on village associations, with the loosening of informal social controls spurring an epidemic of urban delinquency throughout the Global South. ${ }^{40}$ This conception of the urban crisis led many Indian officials to the conclusion that without transforming the attitudes of slum residents themselves - enlisting their pride and participation in the process of urban revitalization - all other measures would ultimately be rendered ineffective. As Nehru put it in 1958, slum improvements 'can only be achieved with the cooperation of the people concerned. This means that every attempt should be made to interest these people, to educate them and to rely upon their help. ${ }^{41}$

India's metropolitan problems were understood to extend beyond the built environment to the 'disordered' communities of its residents. This closely mirrored debates unfolding within the United States, where the 'bricks-and-mortar' emphasis of urban renewal was coming under criticism for neglecting the 'human dimension' of city development. ${ }^{42}$ Both Foundation officials and Indian elites, therefore, were moving towards a strategy of bottom-up 'community development'. Yet transferring this technique from its rural locale in Etawah to the cities of Delhi and Calcutta would be far from straightforward. Indeed, the point was precisely that India's urban centres had lost the organic communal bonds that the rural programmes had built upon. If the Foundation's Etawah project sought to leverage existing village associations towards the process of social change, its urban counterpart set itself a far more ambitious aim: developing entire communities from scratch.

A second difference lay in the cluster of issues that the urban development projects were designed to deal with. While the rural community development project in Etawah tackled low crop yields, disease, and high birth rates, in the cities the key targets were crime and delinquency. It was envisioned that by successfully engineering communal bonds in urban areas the

\footnotetext{
${ }^{37}$ Government of India Planning Commission, Second Five Year Plan (New Delhi: GoI Publications Division, 1956$), 568$. See also Bharat Sevak Samaj, Slums of Old Delhi: Report of the Socio-Economic Survey of the Slum Dwellers of Old Delhi City (Delhi: A. Ram, 1958); Pitambar Pant, 'Urbanization and the Long-Range Strategy of Economic Development', and Sachin Chaudhuri, 'Centralization and the Alternative Forms of Decentralization: A Key Issue', both in India's Urban Future, ed. Roy Turner (Berkeley: University of California Press, 1962), 182-91, and 213-39.

${ }^{38}$ Slum Areas (Improvement and Clearance) Act 1956, 4. See also Pilar Maria Guerrieri, Negotiating Cultures: Delhi's Architecture and Planning from 1912 to 1962 (New Delhi: Oxford University Press, 2018), 30-1.

${ }^{39}$ K. N. Venkatarayappa, Slums: A Study in Urban Problems (New Delhi: Sterling Publishers, 1972), 4, 15, 50.

${ }^{40}$ For India, see Children's Aid Society, A Report on Juvenile Delinquency in India (Bombay: The Children's Aid Society); Sankar Sahai Srivastava, Juvenile Vagrancy: A Socio-Ecological Study of Juvenile Vagrants in the Cities of Kanpur and Lucknow (New Delhi: New Age Printing Press, 1963); Shri S. Venugopal Rao, Facets of Crime in India (Bombay: Allied Publishers, 1963). For elsewhere, see Michael Banton, West African City: A Study of Tribal Life in Freetown (London: Oxford University Press, 1957); Harm J. de Blij, Dar Es Salaam: A Study in Urban Geography (Evanston, IL: Northwestern University Press, 1963). For an overview, see Marshall B. Clinard and Daniel J. Abbott, Crime in Developing Countries: A Comparative Perspective (New York: John Wiley \& Sons, 1973).

${ }^{41}$ Jawaharlal Nehru, 'Foreword', in Samaj, Slums of Old Delhi, 8.

${ }^{42}$ See 'Summary Proceedings of Working Conference on Citizen Participation in Neighborhood Conservation and Rehabilitation', September 1958, reel C-1307, Action Housing, Inc., general correspondence (FA735), FF, RAC.
} 
programme could revitalize the informal social controls that operated in the villages. The resulting nexus of community approval/disapproval could then act as the mechanism for the transmission of 'modern' cultural values, replacing the previously 'apathetic' social environment - tolerant of delinquency and disorder - with a modernizing ethos conducive to order and development. ${ }^{43}$ To an extent quite unlike the previous Ford projects, then, crime prevention was baked into its developmental mission from the outset.

Indeed, this explains why the Ford Foundation chose a criminologist, Marshal Clinard, to head the proposed pilot project in Delhi. Clinard had received his doctoral training at the University of Chicago's Department of Sociology during the late 1930s, at the height of Clifford Shaw and Henry McKay's Chicago Area Project, which sought to combat delinquency through active citizen involvement in the process of local development. ${ }^{44} \mathrm{He}$ envisioned his role in India as analogous to this kind of work, once again dealing with the social problems generated by high levels of rural newcomers to the city. Clinard's work for the Foundation in India, as well as his travels to 'slumimprovement projects' in Europe, Asia, Africa, and Latin America, ultimately led him to see the problem of slums as a 'world-wide phenomenon'. ${ }^{45}$ As he put it in 1966, 'Bombay has its packed multistoried chawls, New York its Harlem and its Lower East Side, Chicago its Black Belt, and London its well-known East End ... Then there are the tin shacks, bamboo huts, and straw hovels along the small lanes of Calcutta, Dacca, and Lagos. ${ }^{36}$

\section{The Delhi pilot project}

In early 1954 India's health minister, Rajkumari Amrit Kaur, contacted Ford's India representative, Douglas Ensminger, regarding the possibility of developing a regional plan for Delhi. The two began formulating a foreign assistance programme, eventually agreeing that a team of foreign specialists would be brought to India to assist in the drawing up of a masterplan. It was also decided that the Foundation would 'start helping to create ... pilot Urban Community Development projects'. ${ }^{47}$ In September 1958 this scheme was launched in Delhi, funded by an initial $\$ 25,000$ grant from the Ford Foundation and a subsequent grant for $\$ 155,539$ to assure the continuation of the programme until at least March 1962. It was overseen by Bimalananda Chatterjee, who headed up the newly created Department of Urban Community Development (DUCD), while Marshall Clinard was appointed as the Foundation's chief consultant. $^{48}$

The key issue that the project was designed to tackle was rural-to-urban migration to Delhi from the surrounding countryside. According to Chatterjee, the rapid and unplanned nature of this demographic shift was preventing the city from performing its appropriate function in the development process. Instead of modernizing under the pressure of city living, rural newcomers seemed to be merely carrying their 'backward' habits with them into the city. As he observed in a 1962 field report, 'People in the cities find themselves in a vortex of change and yet, pathetically, cling to old ideas, associations, habits and customs.' He concluded that this

\footnotetext{
${ }^{43}$ Marshall B. Clinard, 'The Organization of Urban Community Development Services in the Prevention of Crime and Juvenile Delinquency, with Particular Reference to Less Developed Countries', International Review of Criminal Policy no. 19 (1962): 3-12.

${ }^{44} \mathrm{O}$ 'Connor, Poverty Knowledge, 77-85.

${ }^{45}$ Clinard, Slums and Community Development, viii.

${ }^{46}$ Ibid., 3.

${ }^{47}$ Albert Mayer, 'India Newsletter', 22 July 1957, 1-4, folder 12, box 2, Albert Mayer Papers, Manuscripts and Archives Division, New York Public Library. For the Delhi masterplan, see Sanjeev Vidyarthi, 'Inappropriately Appropriated or Innovatively Indigenized? Neighborhood Unit Concept in Post-Independence India', Journal of Planning History 9, no. 4 (2010): 260-76.

${ }^{48}$ Marshall B. Clinard, Ford Foundation Program Letter, India: Report no. 112, 'Report of a Pilot Project in Urban Community Development', May 1960, 1-2, box 26, reports 1-3254 (FA739A), catalogued reports, FF, RAC.
} 
was a problem rooted in the 'heterogeneity of the urban complex', an absence of community which mitigated against the transmission of modern values by providing anonymity for those holding onto old habits. ${ }^{49}$ By engineering fresh communities out of this mass of recent arrivals - fractured by various caste-based and religious solidarities - one could generate a mechanism for infusing 'modern' values throughout the city.

In order to create these communities, the DUCD established a pyramid-like democratic structure which sought to ensure the participation of all segments of Delhi society. In each of the project areas, local organizers were sent to conduct a survey of the neighbourhoods, detailing their physical features (schools, playgrounds, temples) as well as their social fractures according to caste, occupation, and religion. ${ }^{50}$ This necessitated each community organizer going door to door, canvassing residents on their problems and encouraging them to think about changes which could be made within the community. ${ }^{51}$ The area was then divided into sub-blocks of around fifteen to twenty-five families, each of which were formed into 'citizen discussion groups' to encourage them to swap local grievances and elect a representative to serve on the citizens' development council (vikas mandal). Acting as 'the cornerstone of the urban community development project', each vikas mandal was made up of ten to fifteen representatives from the sub-blocks and had authority over 250-400 families. ${ }^{52}$ It was here that most of the self-help projects were to be initiated. By March 1960 there were around two hundred of these playing out across the six vikas mandals. These ranged from neighbourhood beautification campaigns and immunization drives to weekly sewing classes for women and the establishment of local cricket teams. ${ }^{53}$

The actual process of developing communities was more important than the specific content of these projects. 'The crucial aspect of the program is the involvement of the people themselves in neighborhood organizations', one Foundation review put it: 'the specific nature of the problem is relatively unimportant'. ${ }^{54}$ The Commissioner of Delhi agreed, arguing that the programme's principal objective was that of 'giving form to an urban community which has been drawn from backgrounds varying from one another'. ${ }^{55}$ It was in the crucible of local engagement that communities would be forged, melded together through the face-to-face deliberation that came with paving a street, combating delinquency, or lobbying local authorities to install streetlights and water taps. ${ }^{56}$ Such efforts were designed to encourage the psychological integration of rural newcomers, a process tightly linked to the goal of modernization; by identifying with the newly formed community centred around the vikas mandal, in-migrants would shed their previous adherence to 'backward' caste-based and religious solidarities. ${ }^{57}$

The participation of Delhi's most impoverished residents was therefore the key component of the project, playing a therapeutic role in the engineering of 'well-adjusted' urban citizens. A 1964 internal summary for the DUCD noted that the programme's 'underlying objective' was 'to educate public opinion about the importance of community work through citizen participation', thus achieving 'the economic, social, cultural and moral uplift of the residents' ${ }^{58}$ Because those deemed most in need of this economic and psychological development were the urban poor, encouraging

\footnotetext{
${ }^{49}$ Chatterjee, Ford Foundation Program Letter no. 132, 11.

${ }^{50}$ Department of Urban Community Development (hereafter cited as DUCD), 'Monthly Report of Shora Kothi Neighborhood No. 2 for April 1960', 1, C-67, Community Social Development, Municipal Corporation of Delhi (hereafter cited as CSD, MCD).

${ }^{51}$ DUCD, 'Shora Kothi - Project III: Monthly Report for the Month of July',1959, 1-2 C-67, CSD, MCD.

${ }^{52}$ Chatterjee, Ford Foundation Program Letter No. 132, 4.

${ }^{53}$ John Kennedy, 'A Report on Urban Community Development Projects in Delhi and Ahmedabad', 14 July 1966, report no. 007865, box 137, reports 6262-9286 (FA739C), catalogued reports, FF, RAC.

${ }^{54}$ Ibid., 2.

${ }^{55}$ DUCD, Second Evaluation Study of the Vikas Mandals (Delhi: Municipal Corporation of Delhi, 1965).

${ }^{56}$ DUCD, 'Monthly Report of Shora Kothi Project V Area for the Month of February, 1960', C-67, CSD, MCD.

${ }^{57}$ Marshall Clinard and Bimalananda Chatterjee, 'Urban Community Development', in India's Urban Future, ed. Turner, 71-93.

${ }^{58}$ DUCD, [no title; subject: 'Panchim Delhi Vikas Samiti'], c. 1964, 1, file no. 2, R-204, C-67, CSD, MCD.
} 
their involvement in neighbourhood projects was crucial. Chatterjee, after acknowledging that some saw problems with promoting self-help among the poor, counselled that experience had shown the exact opposite: 'the poorer a person, the more easily [sic] it is to motivate him to share with others' ${ }^{59}$ And reports from community organizers in the field frequently stressed how the blocks they worked with were 'inhabited by very low income groups' ${ }^{60}$

The participatory emphasis of the programme was particularly visible in the increasing though still limited - role that women were expected to play in projects. In each sub-block two of the community organizers were usually women. These were tasked with organizing the election of women's auxiliaries (mahila samitis), from whom two representatives were sent to serve on the executive committee of the vikas mandals. ${ }^{61}$ This engagement was justified with reference to the social development and psychological adjustment of the community. Because women were thought to be the main transmitter of values to the next generation, it was 'necessary to involve them effectively in the process of social change', Chatterjee argued, who also observed that women were 'by and large more motivated to seek toward change than men'. ${ }^{62}$ The reports of community organizers were more ambivalent. While some stressed women's 'great interest' in the programme, others noted their high levels of reluctance; when one community worker suggested that the women of a katra pool their resources to make repairs they demurred, replying that it would not be possible for them as they could not pay even a single penny unless their husbands agree' ${ }^{63}$

Aside from the therapeutic benefits provided by community participation, the other salient aspect of the programme was its low cost for the government. With the scale of India's urban problems apparently outrunning the level of assistance its government could feasibly provide, the mantra of 'self-help' in urban development took on a particular resonance. ${ }^{64}$ The DUCD's 1962 review noted how the 'social integration' of the local community was essential in order to make 'maximum use of community resources' for urban regeneration. ${ }^{65}$ The repairing and construction of drains, the installation of water taps, and the painting of houses were all projects undertaken by vikas mandals, carried out by local residents and paid for by their subscriptions. ${ }^{66}$ Family planning and health classes were sponsored by the mahila samitis, which sought to inculcate 'modern' practices by involving the community in group discussions. ${ }^{67}$ Self-help schools, community reading rooms, and neighbourhood immunization campaigns were all part of a coordinated attack on urban 'underdevelopment' which required minimal government spending.

This is partly why the experiment appealed to Nehru's government. A national programme was rolled out in 1965 of twenty community development projects, with matching grants from the Ministry of Health to state and municipal governments. ${ }^{68}$ This was explicitly based on the two projects that the Ford Foundation had pioneered in Delhi and Ahmedabad. ${ }^{69}$ A particularly notable experiment was that begun in Hyderabad in 1967, which was expanded to include the entire

\footnotetext{
${ }^{59}$ Chatterjee, Ford Foundation Program Letter No. 132, 6-8.

${ }^{60}$ DUCD, 'Shora Kothi Neighborhood Monthly Report April, 1961. Pr. IV', 1, C-67, CSD, MCD. See also DUCD, 'Monthly Report of Project of Project 2 (for February), 1960, Shora Kothi Neighborhood', 1, C-67, CSD, MCD.

${ }^{61}$ Chatterjee, Ford Foundation Program Letter No. 132, 15-16.

${ }^{62}$ Ibid., 8.

${ }^{63}$ DUCD, 'Shora Kothi Neighborhood Report for the Month of April', 1961, 9, C-67, 1961, CSD, MCD.

${ }^{64}$ Subhash Chandra, 'An Evaluation of Urban Community Development in India', Community Development Journal 9, no. 3 (1974): 191-202.

${ }^{65}$ DUCD, 'A Review, September 1958-March 1962', report no. 001014, 2, R-9031, box 41, reports 1-3254 (FA739A), catalogued reports, FF, RAC.

${ }^{66}$ DUCD, 'Shora Kothi Neighborhood Monthly Report for October, 1960. Project II', 2, C-67, CSD, MCD.

${ }^{67}$ Clinard, Slums and Community Development, 216-25.

${ }^{68}$ R. S. Gupta, 'Urban Community Development in India: Some Administrative Aspects', Community Development Journal 5, no. 2 (1970): 94-7.

${ }^{69}$ Government of India, Ministry of Health, Report of the Rural-Urban Relationship Committee (New Delhi: Government of India Press, 1966).
} 
city over the next twenty years. Financed with support from UNICEF during the 1970s, the Hyderabad municipal corporation collaborated with representative committees to deliver improved social services, rehabilitated amenities, and housing- and business-related loans. ${ }^{70}$ One 1979 review concluded that the project demonstrated how 'any neighborhood, no matter how poor, can do something to improve itself by its own efforts [through] a gradual process of education, community action and self help'. ${ }^{71}$

It was not just in India where the lessons of the Delhi pilot project would be applied. Its methods were deemed to be applicable around the world, and the programme evoked a considerable amount of international interest. The DUCD was inundated with requests for literature from the planning commissions of foreign governments. In 1962, the government of Hong Kong sent members of its Social Welfare Department to Delhi to undertake a study of the programme, following in the footsteps of a host of town planners and social workers who visited from all over the world. That same year, the UN requested that the DUCD set up on-the-ground training facilities for government officials from Somaliland for a period of eight weeks. ${ }^{72}$ Articles from Chatterjee and Clinard outlining the project also featured in self-consciously global journals such as Ekistics and the International Review of Community Development. ${ }^{73}$ An issue of the Journal of Housing published in the United States devoted a considerable portion to the Delhi experiment. This was entirely appropriate: as the following section will show, it was in America that its lessons would be most thoroughly applied.

\section{Maximum feasible participation}

The community action approach was central to the Ford Foundation's pioneering efforts to deal with America's declining inner cities. At the turn of the 1960s, it began funding a number of projects - most importantly its 'Gray Areas' programme - which sought to harness the participation of impoverished residents themselves in the process of city development. ${ }^{74}$ Like the Indian project, the core goal of these measures was the social development and cultural assimilation of recent rural migrants to the cities. As they shared a transnational culture of 'underdevelopment' with their Indian counterparts, it was thought that these 'newcomers' to America's cities - from Puerto Rico, the US South, Mexico, and Appalachia - could similarly be forged into modern citizens through the process of expert-assisted community building. ${ }^{75}$

The Ford Foundation's emphasis on the problem of rural-to-urban migration was largely down to the influence of Paul Ylvisaker. Hired to the Public Affairs division in 1955, Ylvisaker pulled the Foundation in the direction of his own intellectual evolution. This had shifted away from his desire to reform metropolitan governance structures - better integrating the interests of the suburbs and the inner city - and towards a tighter focus on the 'human problems' of so-called

\footnotetext{
${ }^{70}$ A. Malla Reddy, Slum Improvement: The Hyderabad Experience (Delhi: Bookwell Publishers 1996).

${ }^{71}$ William J. Cousins and Catherine Goyder, Changing Slum Communities: Urban Community Development in Hyderabad (New Delhi: Manohar, 1979), 14.

${ }^{72}$ DUCD, 'Review, September 1958-March 1962', 12.

${ }^{73}$ Bimalananda Chatterjee, 'India Applies Rural Techniques of Self-Help to Rapidly Growing City Neighborhoods', Journal of Housing 18, no. 5 (1961): 193-7; Marshall B. Clinard, 'The Delhi Pilot Project in Urban Community Development', International Review of Community Development 7 (1961): 161-70; Bimalananda Chatterjee, 'India Applies Rural Techniques of Self-Help to Rapidly Growing City Neighborhoods', Ekistics 12, no. 72 (1961): 281-3.

${ }^{74}$ For scholarship on the Gray Areas programme, see Robert Halpern, Rebuilding the Inner City: A History of Neighborhood Initiatives to Address Poverty in the United States (New York: Columbia University Press, 1995); O'Connor, 'Community Action', 586-625.

${ }^{75}$ Oscar Handlin, The Newcomers: Negroes and Puerto Ricans in a Changing Metropolis (Cambridge: Harvard University Press, 1959).
} 
'gray areas'. ${ }^{76}$ These were the decaying residential zones which ringed the central business district, separating it from the more affluent suburbs. ${ }^{77}$ For Ylvisaker, these neighbourhoods had traditionally played the role of 'citifying our in-migrant populations', acting as places of 'transition' for 'the immigrant from abroad, for the rural uprooted, for a wide assortment of human beings who are at the bottom of their life's ambitions' ${ }^{78}$ Yet with the flight of industry to the suburbs these modernizing zones had congealed into stagnant backwaters, pockets of underdevelopment permanently inhabited by 'those who are even more rural and backwards in culture', Ylvisaker argued: 'Negroes from the rural South; mountain folk from the Ozarks and Appalachians, Puerto Ricans from their island villages'. ${ }^{79}$

Ylvisaker saw America's urban crisis as rooted in the 'backward' cultures which migrants were carrying with them into the city. It was therefore identical to the situation described in Bimalananda Chatterjee's field reports from India, leading to the same cluster of problems of delinquency, blighted housing, and unemployment. ${ }^{80}$ Specificities in the American case were collapsed into a transnational nexus of problems coalescing around the 'backward' cultural habits of rural migrants and the 'disordered' community structures that underpinned them - a conception of America's urban crisis that elided the profoundly structural reasons for the entrapment of people of colour in the inner cities. This was the conceptual alchemy which allowed Ylvisaker to transform domestic deprivation into a global developmental problem whose solution lay in the psychological modernization of its residents.

In these circumstances the Ford Foundation acted as an institutional bridge, facilitating the transnational cycling of techniques between India and the United States. This dynamic was illustrated starkly in one exchange which took place in 1959. After holding a conference on the importance of 'citizen participation' in urban renewal, the Foundation consultant Bernard Loshbough sent the proceedings to George Gant, programme representative in Pakistan. ${ }^{81}$ Gant was out of town, but his secretary replied informing Loshbough that he had forwarded the report on to Douglas Ensminger, 'who will, I know, be interested in it in connection with a pilot project in urban community development which the Ford Foundation is helping to support in India' ${ }^{82}$ 'I guess nobody told you I was formerly Deputy Representative in India for the Ford Foundation', Loshbough replied, who had already sent several copies of the report to Ensminger a few days earlier. ${ }^{83}$ It was during his stint in India between 1953 and 1956 that Loshbough had first formulated his ideas on community development, 'develop[ing] the notion that this approach could be adapted to the urban areas of the United States' ${ }^{84}$ The same was true

\footnotetext{
${ }^{76}$ See Paul Ylvisaker, 'Diversity and the Public Interest: Two Cases in Metropolitan Decision-Making', Journal of American Institute of Planners 27, no. 2 (1961): 107-17. For the evolution of Ylvisaker's thinking, see Ferguson, Top-Down; and Immerwahr, Thinking Small.

${ }^{77}$ Paul Ylvisaker, 'Metropolitan Government - For What?', 24 July 1958, report no. 019247, reports 17727-19980 (FA739G), catalogued reports, FF, RAC.

${ }^{78}$ Paul Ylvisaker, 'Planning in a Period of Change: A Luncheon Address, 1958 Annual Conference of the American Institute of Planners, New York City', 27 October 1958, 1-14, box 424, reports 9287-11774 (FA739D), catalogued reports, FF, RAC.

${ }^{79}$ Paul Ylvisaker, 'The University in a Changing Urban Environment', 3 November 1958, reports 17727-19980 (FA739G), catalogued reports, FF, RAC.

${ }^{80}$ Kenneth Clarke, Dark Ghetto: Dilemmas of Social Power (London: Victor Gollancz, 1965).

${ }^{81}$ Bernard Loshbough to George Gant, 21 January 1959, reel C-1307, Action Housing, Inc., general correspondence (FA735), FF, RAC.

${ }^{82}$ Walter Rudlin to Bernard Loshbough, 2 February 1959 reel C-1307, Action Housing, Inc., general correspondence (FA735), FF, RAC.

${ }^{83}$ Bernard Loshbough to Walter Rudlin, 9 February 1959 reel C-1307, Action Housing, Inc., general correspondence (FA735), FF, RAC.

${ }^{84}$ Richard Catalano, 'ACTION-Housing Urban Extension Program: Office of Policy and Planning', April 1964, 2, folder 3, box 14, Office Files of Wilson McNeil, Series IV: Programs (FA582) (hereafter cited as OFWM), FF, RAC.
} 
for Ylvisaker, who could also be found shuttling between New York and India during the early 1960s. ${ }^{85}$

The Foundation's international development efforts overseas encouraged the organization to utilize a bottom-up, community-orientated approach in its response to America's urban crisis. This was reflected in its Gray Areas programme undertaken at the turn of the 1960s, which sought to institutionalize community responses to the interlinked problems of poverty and delinquency. As Alice O'Connor has shown, this project drew on the work of the sociologists Richard Cloward and Lloyd Ohlin, whose Delinquency and Opportunity (1961) had argued that delinquent subcultures were the consequence of blocked opportunities for legitimate advancement. ${ }^{86}$ Yet they also employed the urban community development strategies that Ford were pioneering overseas, where its Delhi pilot project sought to deal with a similar cluster of problems around rural inmigration, poverty, and delinquency. An analogous process of community reintegration as that performed in the 'slums' of India was required in order to restore America's 'gray areas' to their role as modernizing enclaves. ${ }^{87}$

Community building through local participation lay at the heart of the Gray Areas programme. Between 1961 and 1967 a series of community action grants were made to five cities - Boston, Philadelphia, New Haven, Washington, DC, and Oakland - as well as the state of North Carolina. In each city an independent, non-profit corporation was established, tasked with utilizing Ford grants to formulate a coordinated response to poverty and delinquency. ${ }^{88}$ The central function of these corporations was to democratize the planning and provision of social services, encouraging the 'active participation' of the neighbourhood by allowing its residents to express 'their own felt needs' ${ }^{89}$ In the Oakland project, for instance, a citizens advisory committee of community leaders was set up to review the proposals formulated by the Interagency Project. ${ }^{90}$ Both the New Haven and the Washington corporations established neighbourhood service teams which were tasked with 'stimulating self-help activities' and helping residents 'identify local problems'. ${ }^{91}$ Like the Delhi project, this participatory emphasis was intimately linked to the process of social development. As one Foundation review put it, the Gray Areas corporations 'seek to encourage urban communities to fashion more effective ways to speed the transition of the urban in-migrant and slum residents of low educational achievement and inadequate work skills to full economic, social and cultural participation in the urban community'. ${ }^{92}$

This analysis indicates the ways in which structural and cultural explanations for poverty could bleed into one another. While the Ohlin-Cloward thesis of urban deprivation stressed the importance of racial discrimination and capital flight, these factors were routinely collapsed into a 'cycle of poverty' argument whereby the cultural pathologies bred by these structural disadvantages took on a life of their own..$^{93}$ This trend was compounded at Ford by Ylvisaker's emphasis on achieving the cultural integration of recent urban in-migrants, as well as racist assumptions regrading the

\footnotetext{
${ }^{85}$ This is detailed in Bernard Loshbough, 'Calcutta Metropolitan Planning Organization: Report and Recommendations', 1 May 1962, report no. 000687, 5-7, box 35, reports 1-3254 (FA739A), catalogued reports, FF, RAC.

${ }^{86} \mathrm{O}$ 'Connor, Poverty Knowledge, chap. 5. See also Lloyd Ohlin and Richard Cloward, Delinquency and Opportunity: A Theory of Delinquent Gangs (London: Routledge \& Kegan Paul, 1961).

${ }^{87}$ Paul Ylvisaker, 'Opening Minds and Expanding Cities', 3 December 1959, reports 17727-19980 (FA739G), catalogue reports, FF, RAC.

${ }^{88}$ Memorandum from Barton R. Clausen and James S. Howard to Paul Ylvisaker, 31 January 1964, 1, box 622, reports 11775-13948 (FA739E), catalogued reports, FF, RAC.

${ }^{89}$ David Hunter, 'A Neighborhood Approach to Juvenile Delinquency', 4 May 1960, report no. 0010462, 4, reports 9287-11774 (FA739D), catalogued reports, FF, RAC.

${ }^{90}$ Public Affairs Division, 'Review Paper: Gray Areas Program', September 1964, 3, box 16, Office Files of Louis Winnick (FA601), FF, RAC.

${ }^{91}$ Ibid., 5; Kathleen D. McCarthy, 'Anti-Delinquency, Great Cities, Gray Areas', May 1989, report 012158, FF, RAC.

${ }^{92}$ Public Affairs Division, 'Review Paper', 1.

${ }^{93}$ See Michael Harrington, The Other America: Poverty in the United States (New York: Macmillan, 1962). For an excellent analysis of this, see Hinton, From the War on Poverty, 27-63.
} 
'less assimilable' nature of African American and Puerto Rican people. ${ }^{94}$ Cultural enrichment was one solution, with Gray Areas corporations undertaking a series of educational, health, and recreational programmes. ${ }^{95}$ As one review noted, the primary purpose of these programmes was 'to shorten the period of acculturation for successive groups of migrants into the city'. This was underpinned by 'the notion that the urban Negro is culturally deprived'. ${ }^{96}$

This cultural backwardness was understood to be the root cause not only of poverty but also of crime in America's urban cores. Indeed, Ford's urban community development projects were underpinned by a conceptual linkage between development and 'law and order'. ${ }^{97}$ As the programme officer David Hunter explained, violence and disorder thrived in 'backward' communities. The Gray Areas programme had 'to change the climate of the neighborhood from one of frustration to one of hope', which could be achieved by ensuring the residents be made to 'feel that they too have a stake in making things better. ${ }^{98}$ Mobilization in one area was to have ripple effects elsewhere, restoring pride in the neighbourhood and re-energizing the informal social controls that acted to both prevent crime and encourage psychological acculturation. In a similar fashion to many US aid programmes overseas, therefore, the development of US urbanites was tightly linked to the pacification of their turbulent communities. ${ }^{99}$

\section{Maximum feasible misunderstanding}

In theory, developing communities through a process of 'maximum feasible participation' was supposed to bring order and modernization to the urban space. Yet in practice the Ford Foundation found that this technique worked to mobilize urban residents in quite unexpected ways. As the projects unfolded in both India and the United States, Ford's efforts appeared to mobilize and radicalize the very residents they were attempting to modernize and pacify. This pointed to a fundamental disjuncture between the Ford Foundation and the communities they encountered; while Ford envisioned the projects as engineering a consensual process of social change, many urban residents sought to utilize the participatory structures they put in place to push for more fundamental shifts in the local balance of power.

In the United States, these controversies were thrust into mainstream consciousness after community action agencies began clashing with established municipal authorities over issues of housing, welfare, and policing. With the War on Poverty's strategy of 'maximum feasible participation' consequently coming under fire, the Ford Foundation's role in democratizing urban planning was subjected to intense scrutiny. As the most visible edge of the social scientific 'expertise' that Daniel Patrick Moynihan would so excoriate in his Maximum Feasible Misunderstanding (1969), it was thrust into a contentious national debate over racism, poverty, and democracy. ${ }^{100}$

Ylvisaker referred to the Gray Areas programme as 'a revolution within the establishment'. ${ }^{101}$ This awkward phrasing reflected the difficulties that the Foundation had in balancing its goal of community mobilization with its desire to work with established city governance structures. As

\footnotetext{
${ }^{94}$ Inter-Office Memorandum from Gordon Harrison to Richard Sheldon, 6 July 1964, 4, folder 2, box 17, OFWM Series IV: Programs (FA582), FF, RAC.

${ }^{95}$ Inter-Office Memorandum from Gordon Harrison to William McPeak, 7 May 1963, 1, folder 8, box 13, OFWM Series IV: Programs (FA582), FF, RAC.

${ }^{96}$ Memorandum from Harrison to Sheldon, 6 July 1964, 8.

${ }^{97}$ Clinard, 'Organization of Urban Community Development Services', 3-16.

${ }^{98}$ Hunter, 'Neighborhood Approach to Juvenile Delinquency', 3-5.

${ }^{99}$ Ananya Roy, Emma Shaw Crane, and Stuart Schrader, “The Anti-Poverty Hoax”: Development, Pacification, and the Making of Community in the Global 1960s', Cities: The International Journal of Urban Policy and Planning, 44 (2015): 139-45.

${ }^{100}$ Annelise Orleck and Lisa Gayle Hazirjian, eds., The War on Poverty: A New Grassroots History, 1964-1980 (Athens, GA: University of Georgia Press, 2011); Daniel Moynihan, Maximum Feasible Misunderstanding: Community Action in the War on Poverty (New York: The Free Press, 1969).

${ }^{101}$ McCarthy, 'Anti-Delinquency', 29.
} 
one early assessment of the project pointed out, there were 'complicated political stresses' generated by the fact that Gray Area corporations existed 'outside the central power structure'. 'The opportunities for conflict are legion', it concluded presciently. ${ }^{102}$

In Boston, these frictions quickly emerged after the board of Action for Boston Community Development (ABCD) was gradually expanded to include lower-income residents. Neighbourhood organizations were also established to help locals express their 'felt needs' to city authorities. Soon complaints were being made through these bodies regarding segregated educational structures, inadequate housing, and poor municipal services, culminating in a series of highly publicized confrontations with City Hall. ${ }^{103}$ At the prompting of the embarrassed Ford Foundation, ABCD gradually abandoned its community organization role, a move which mollified the mayor but came at the price of 'the agency's prestige in low-income communities' ${ }^{104}$

A similar pattern of conflict followed by retreat characterized the other projects. In New Haven the Gray Area corporation, Community Progress Inc. (CPI), became embroiled in a controversial rape trial after one of its staff lawyers, Jean Cahn, opted to represent one of the three African American men accused. A young African American graduate of Yale Law School raised in a Baltimore household frequented by Paul Robeson and Thurgood Marshall, Cahn was deeply committed to the civil rights struggle. ${ }^{105}$ Her involvement in the case drew the ire of Mitchell Sviridoff, director of CPI and future vice-president at the Ford Foundation. For Sviridoff, maintaining good relations with Mayor Richard Lee was more important than encouraging the participation of New Haven's African American community. With public outrage over Cahn's involvement putting pressure on Lee, Sviridoff refused to publicly identify the CPI with her defence. Shortly after losing the case, Cahn resigned in protest. ${ }^{106}$ The pressure points of this particular saga - with its entangling of community participation with the fraught issue of racism - were a harbinger of things to come.

Nowhere was conflict quite so intense as over Mobilization for Youth (MFY), a Foundationfunded community action group located on Manhattan's Lower East Side. ${ }^{107}$ Begun as a traditional social service programme, by 1962 it had shifted in emphasis towards a particularly militant form of community action, seeking to organize the poor as an independent source of power. Its local organizers played a critical role in establishing Mobilization of Mothers, a group of largely Puerto Rican women which pressed complaints about the standards of their children's education to local superintendents. The radical edge of MFY only intensified with the cresting of the northern civil rights movement by the middle of the decade, after which it began coordinating a series of rent strikes, boycotts, and protests. ${ }^{108}$ By 1964 these activities had come under intense criticism, with local publications charging that MFY was littered was communist sympathizers and behind the Harlem riots that summer. ${ }^{109}$

The Ford Foundation balked at the negative publicity generated by the scandal. Ylvisaker dismissed the programme as 'too radical', while Sviridoff complained that the anti-poverty

\footnotetext{
${ }^{102}$ Memorandum from Harrison to McPeak, 1.

${ }^{103}$ National Affairs/Social Development, 'United Two Americas (working title)', 1967, 43-9, box 60, reports 1-3254 (FA739A), catalogued reports, FF, RAC.

${ }^{104}$ Ibid., 49.

${ }^{105}$ Steven Waldman, 'A Perfect Combination of Chutzpah and Soul', Washington Post, 18 August 1991.

${ }^{106}$ Edgar Cahn and Jean Cahn, 'The War on Poverty: A Civilian Perspective', Yale Law Journal 73, no. 8 (1964): 1317-52; Peter Marris and Marin Rein, Dilemmas of Social Reform: Poverty and Community Action in the United States (London: Routledge, 1967), 171-3.

${ }^{107}$ For a superb recent account of Mobilization for Youth's activities, see Tamar W. Carroll, Mobilizing New York: AIDS, Antipoverty, and Feminist Activism (Chapel Hill: University of North Carolina Press, 2015).

${ }^{108}$ Nancy A. Naples, Grassroots Warriors: Activist Mothering, Community Work, and the War on Poverty (New York: Routledge, 1998), 78-81; Carroll, Mobilizing New York, 22-78.

109،Anti-JD Agency Probed for Red Ties', Daily News, 16 August 1964, 2; 'Youth Agency Chief: Maybe Lefties Got in', Daily News, 17 August 1964, 3; 'Mayor Orders Youth Agency Probe', Daily News, 18 August 1964, 3; 'Rent Strikes Hear Speakers Hail the MFY', Daily News, 30 August 1964, 12.
} 
movement had become 'more concerned with the process of participation than with ... substantive results'. ${ }^{110}$ By 1965 the Foundation were already reducing their support. This heralded a broader shift in their urban programming, which began downplaying the participatory aspects of their Gray Areas projects and emphasizing instead 'concrete outputs, rather than protest and advocacy'. ${ }^{111}$ Sviridoff's New Haven project became the model in this regard. Since the Jean Cahn controversy, the CPI had abandoned its community organization function and tightened its links with Mayor Lee. While early reports had criticized this 'executive-centred' structure, it was soon being pinpointed as the central reason for CPI's success: 'Unlike several other Gray Areas programs,' one report approvingly noted, 'CPI never succumbed to the centrifugal forces unleashed by the push to achieve "maximum feasible participation".'112

These shifts in Ford programming dovetailed with a broader move away from 'maximum feasible participation' after 1966 throughout the United States. As Stuart Schrader has argued, this was a shift not necessarily replicated in US development projects abroad: the Foreign Assistance Act (1966) embedded community participation even more closely into overseas development projects, particularly in the case of America's 'pacification' efforts in Vietnam. ${ }^{113}$ The evolution of Ford's programmes in India, however, reveals an alternative genealogy, whereby the difficulties of encouraging participation overseas appeared be unfolding in tandem with the crises of the War on Poverty at home. Indeed, a look at Ford's progress reports - as well as field notes of the community organizers on the ground in India - shows how the projects were plagued by strikingly similar problems to those in US cities.

In Delhi, the project struggled to reconcile its stated desire to achieve 'the active cooperation of citizens' with its aversion to antagonizing local power structures. ${ }^{114}$ For both Ford and local community organizers, the mobilization of sub-block residents was supposed to achieve consensus within the community, bringing together its various representatives in order to transcend the boundaries of class, caste, and even religion. As an early field report noted enthusiastically, while previously 'members formed as hetrogenous [sic] groups' based on 'the professions \& vocations they followed', the sub-block meetings ensured that 'from washermen to college professors, all were sitting together'. ${ }^{115}$ Convenors of vikas mandal meetings were explicitly instructed 'not [to] say anything which might have a political implication'. ${ }^{116}$ They did so by focusing the agenda on relatively anodyne issues such as whitewashing houses, purchasing common dustbins, and neighbourhood inoculation campaigns. ${ }^{117}$

Some issues, however, proved beyond the consensus-building efforts of the community workers. Particularly intractable were the fraught issues surrounding housing and tenant-landlord relations. While notably absent from Clinard's published account of the project, these conflicts litter the pages of field reports from community organizers in Delhi. Reports often began by pointing to the 'very strained' nature of the relations between tenants and landlords, with residents complaining of landlords living outside the area and consequently being 'the least bothered by the

\footnotetext{
${ }^{110}$ McCarthy, 'Anti-Delinquency', 49, emphasis added.

${ }^{111}$ National Affairs Division, 'The Foundation's Community Development Program: Information Paper', September 1971, 8, box 78, reports 1-3254 (FA739A), catalogued reports, FF, RAC.

${ }^{112}$ For the early memo, see Memorandum from Harrison to McPeak, 2. For the later quote, see McCarthy, 'AntiDelinquency', 37.

${ }^{113}$ Stuart Schrader, 'To Secure the Global Great Society: Participation in Pacification', Humanity 7, no. 2 (2016): 225-53; Schrader, Badges Without Borders, 161-64.

${ }^{114}$ Sri Bimalananda Chatterjee, 'Office Note No. 3286/II/UCD', 8 August 1961, 1, 'Nagar Vikas Sammelan', MCD.

${ }^{115}$ DUCD, 'Project Shora Kothi: Monthly Report for August, 1959', 2, C-67, 1959, CSD, MCD.

${ }^{116}$ DUCD, 'Shora Kothi Neighborhood Project II Monthly Report for the Month of May 60', 1, C-67, CSD, MCD. See also DUCD, 'First Nagar Vikas Samelan, 30th September \& 1st October', 1961, 2, C-67, CSD, MCD.

${ }^{117}$ Clinard, Slums and Community Development, 208-34.
} 
inconveniences to the tenants'. ${ }^{118}$ Yet when these harassed tenants took their complaints to the vikas mandal, the organization's attempts to get both sides to 'merge their differences' through a series of mediative meetings invariably ran up against the entrenched positions of each. ${ }^{119}$ After reaching this impasse, the vikas mandal usually recoiled from pushing the matter any further, citing their determination to avoid 'such disputes which were impossible to solve except through a court of law, or where some violence would be an easy outcome'. ${ }^{120}$

This hardly satisfied the residents. They often shunned the mediative efforts of the vikas mandal and took matters into their own hands. In Project Area II of the Shora Kothi neighbourhood, the vikas mandals sought to broker a dispute in one of the katras by getting both the tenants and the landlord to contribute equally for repairs. While initially agreeable, the residents scuppered the deal at the last minute, demanding instead that the landlord pay the full amount. According to the community organizer's exasperated report, the tenants had been 'incited' into action by 'people living close to this katra' - an ominous reference to an earlier accusation that its local millworkers were affiliated with the Community Party. ${ }^{121}$ In Project Area IV of the same neighbourhood, the community organizer bemoaned 'the dominant tendency in the people to fight out lawsuits rather than deciding things peacefully'. He conceptualized his role as restraining the radicalism of the tenants, channelling it into more 'productive' and less confrontational avenues, concluding after one particularly fiery meeting, 'the residents of the area need a very gradual nursing along. ${ }^{122}$

By 1962, these conflicts had begun to surface in Chatterjee's reports back to the Ford Foundation. There was an acute 'problem of rising expectations', he complained in February 1963. ${ }^{123}$ Once 'a group organised for cooperative action', Chatterjee observed, 'a stage is likely to be reached when they will demand fundamental alterations rather than minor structural changes in their community life'. ${ }^{124}$ What is more, these demands were not only more radical than either the vikas mandals or the Ford Foundation could stomach, but were also made outside 'traditional administrative procedures or policies'. ${ }^{125}$ This was much to the ire of established neighbourhood organizations, local councillors, and existing municipal authorities, many of whom began to resent the disruptive presence of the vikas mandals within the community.

According to the official Ford review of the project conducted in 1966, the nature of the problem was clear. Because the professional worker was supposed to be a 'catalytic agent who helps the community by awakening its discontent about conditions in the area', it was bound to run head on into more established authorities. ${ }^{126}$ The same report noted the difficulty of ensuring that 'discontent, once it has been aroused, is focused and channelled into organization, planning and action', noting that a failure to do so led to 'increased frustration, apathy and bitterness'. ${ }^{27}$ In Ahmedabad these concerns interacted with suspicion of local authorities towards the Ford Foundation's

\footnotetext{
${ }^{118}$ DUCD, 'Monthly Report of Project 2 (for February) 1960, Shora Kothi Neighborhood', 1-2; DUCD, 'Shora Kothi Project 2. Monthly Report of the Project. Monthly Report for the Month of March, 1960', 2, C-67, CSD, MCD. See also DUCD, 'Monthly Report of Project IV of Shora Kothi Neighborhood for the Month of July, 1960', 1, C-67, CSD, MCD.

${ }^{119}$ DUCD, 'Shora Kothi Neighborhood Monthly Report April, 1961 [Project II]', 1, C-67, CSD, MCD.

${ }^{120}$ DUCD, 'Monthly Report of Project II of Shora Kothi Neighborhood for the month of July, 1960', 1 C-67, CSD, MCD.

${ }^{121}$ DUCD, 'Shora Kothi Neighborhood Monthly Report for May, 1961. Project:-II', 5, C-67, 1961, CSD, MCD.

${ }^{122}$ DUCD, 'Shora Kothi Neighborhood Monthly Report for September, 1960 Project IV', 1-2, C-67, CSD, MCD.

${ }^{123}$ Bimalananda Chatterjee and Marshall Clinard, 'Training Manual: Part IV, Self-Help Activities in Urban Community Development Projects', 25 February 1963, report no. 003173, 17-18, box 141, reports 1-3254 (FA739A), catalogued reports, FF, RAC.

${ }^{124}$ Sri Bimalananda Chatterjee, Program Report No. 130, 'The Delhi Urban Community Development Project, India', 12 July 1962, report no. 001824, 15, box 70, reports 1-3254 (FA739A), catalogued reports, FF, RAC, emphasis added.

${ }^{125}$ Ibid.

${ }^{126}$ Kennedy, 'Report on Urban Community Development Projects', 2.

${ }^{127}$ Ibid., 4.
} 
presence within the country. After a new coalition came to power in 1965, they swiftly closed down the programme owing to 'their antagonism to a foreign foundation'. ${ }^{128}$

The urban projects which continued to operate in India began increasingly circumscribing the extent of citizen participation. This was particularly the case after the national programme was introduced after $1966 .{ }^{129}$ As in the United States, 'programmatic' objectives such the building of physical improvements (toilet blocks or newly paved streets) began to be prioritized over 'participatory' processes of community action. A 1971 survey of seven of the national projects begun in the year 1966-67, including those in Hyderabad, Kanpur, and Sarat, found that only $17.9 \%$ of the residents of each area were found to have 'high' levels of participation, compared to $61.9 \%$ of residents whose engagement was said to be 'peripheral' or 'non-existent'. ${ }^{130}$ In an assessment of the project in Baroda, one author approvingly noted how its planners had 'recognised the danger of creating an exaggerated image of what self-help can achieve'. This was because 'the neighborhood problems are of such a wide variety' that it was clear that the resources and expertise of 'citizens outside the project areas is needed'. ${ }^{131}$

\section{Conclusion}

As this observation suggests, the mobilization of the poor was not only generating conflict with local authorities; it also appeared incapable of dealing with the underlying economic roots of urban poverty. Indeed, numerous evaluations of both the Delhi project and the Gray Areas programme noted how the efforts at 'economic self-help' had all ultimately failed. In Delhi, less than $10 \%$ of vikas mandal activity was devoted to efforts to improve residents' income, while in the US the Gray Area programmes had also been unable to tackle what one historian has labelled 'the problem of jobs' ${ }^{132}$ While youth employment centres were established which sought to link applicants to vacant openings, they could do little to actually create employment opportunities. In Boston just $10 \%$ of the intake were placed in jobs, leaving over a thousand applicants in limbo. ${ }^{133}$

By the mid 1960s the process of community action was being criticized as both inflammatory and ineffective. Rather than modernizing the cultures of recent in-migrants, it appeared to be splintering urban communities along the fraught axes of race, class, and caste. Meanwhile, the chronic levels of joblessness and poverty that remained led many to question the cultural emphasis of the self-help programmes thus far. Both these factors would ultimately re-orientate the focus of the Ford Foundation's efforts to develop urban communities, which after 1966 gradually shifted away from developing the cultures of their marginal inhabitants and towards attracting business, capital, and the affluent back to the cities. As modernization was replaced by this strategy of protogentrification, Ford began focusing on altering who lived in the city, rather than modernizing the behaviour of those who already did.

Sam Collings-Wells is a $\mathrm{PhD}$ candidate at the University of Cambridge. He is writing a thesis on the role of liberal philanthropy in police reform across the United States.

\footnotetext{
${ }^{128}$ Bimalananda Chatterjee, 'A Report Updating Earlier Review by Mr John Kennedy on Urban Community Development in Ahmedabad', 29 November 1969, report no. 007864, 6, box 137, reports 6262-9286 (FA739C), catalogued reports, FF, RAC.

${ }^{129}$ Alan Mayne, Slums: The History of a Global Injustice (London: Reaktion Books, 2017), 183.

${ }^{130}$ Chandra, 'Evaluation of Community Development in India', 191-202.

${ }^{131}$ Chandan Mehta, 'Citizens Participation in Urban Community Development', Community Development Journal 4, no. 1 (1969): 133-6, emphasis added.

${ }^{132}$ Chatterjee and Clinard, 'Training Manual', 53.

${ }^{133}$ Marris and Rein, Dilemmas of Social Reform, 71.
}

Cite this article: Collings-Wells S. 2021. Developing communities: the Ford Foundation and the global urban crisis, $1958-66$. Journal of Global History 16: 336-354, doi:10.1017/S1740022820000200 